\title{
Formulation Development and Evaluation of Fast Disintegrating Tablets of Ambroxol Hydrochloride for Pediatrics- A Novel Approach for Drug Delivery
}

\author{
${ }^{1}$ Deepak Sharma", ${ }^{2}$ Mankaran Singh, ${ }^{3}$ Dinesh Kumar, ${ }^{4}$ Gurmeet Singh, ${ }^{5}$ Mahendra Singh Rathore \\ ${ }^{1}$ Rayat Bahra Institute of Pharmacy, Hoshiarpur-146001, Punjab, India \\ ${ }^{2}$ Quantum Solutions, Chandigarh 160036, India \\ ${ }^{3} \mathrm{CSIR}$ Institute of Microbial Technology, Sector 39A, Chandigarh 160036, India \\ ${ }^{4}$ Guru Nanak Institute of Pharmacy, Dalewal, District: Hoshiarpur-144208, Punjab, India. \\ ${ }^{5}$ Maharishi Markandeshwar University, Mullana- Ambala, 133207, Haryana, India
}

\begin{abstract}
Objective: The objective of the present study was to prepare the fast disintegrating tablet of Ambroxol Hydrochloride for respiratory disorders such as bronchitis, asthma and cough for pediatrics. Material and Methods: The tablets were prepared by direct compression technique. Superdisintegrants such as Sodium Starch Glycolate was optimized. Different binders were optimized along with optimized superdisintegrant concentration. The tablets were evaluated for hardness, friability, weight variation, wetting time, disintegration time and uniformity of drug content. Optimized formulation was further evaluated by in-vitro dissolution test, drug-excipient compatibility and accelerated stability study. Results: Sodium Starch Glycolate was optimized as $4 \%$ for formulation on the basis of least disintegration time. $1 \%$ Microcrystalline Cellulose was selected as optimum binder concentration on the basis of least disintegration time. Percent weight variation and content uniformity was well within the acceptable limit. The friability was less than $1 \%$. The wetting time and disintegration time was practically good for all formulations. The results obtained with FTIR studies and accelerated stability study showed that there was no interaction between the drug and excipients used in the formulation. Conclusion: It was concluded that by employing commonly available pharmaceutical excipients such as superdisintegrants, hydrophilic and swellable excipients and proper filler a fast disintegrating tablet of Ambroxol Hydrochloride for pediatrics used in respiratory disorders were formulated successfully with desired characteristics which disintegrated rapidly; provide rapid onset of action and enhance the patient convenience and compliance.
\end{abstract}

Key Words: Ambroxol Hydrochloride, Fast disintegrating tablet, Sodium starch glycolate, Optimization study, In-vitro Disintegration time.

\section{INTRODUCTION}

Despite of tremendous innovations in drug delivery, the oral route remains the preferred route for administration of therapeutic agents because of accurate dosage, low cost therapy, self medication, non -invasive method and ease of administration leading to high level of patient compliance. ${ }^{1}$ The most popular dosage forms are being conventional tablets and hard gelatin capsules.
One important drawback of such dosage forms is 'Dysphagia' or difficulty in swallowing for many patients; almost $50 \%$ of the population is affected by such problem. Hence they do not comply with prescription, which results in high incidence of non-compliance and ineffective therapy. ${ }^{2}$ Recently, fast disintegrating drug delivery systems have started gaining popularity and
Submission Date : 29-06-13 Revision Date :22-09-14 Accepted Date : :06-11-14

DOI: $10.5530 /$ ijper.48.4s.6 Correspondence Address Prof . Deepak Sharma Assistant Professor Street no 8, Mansa Devi Nagar, Phagwara, District Kapurthala, Punjab, Pin code: 144402

Email: deepakpharmacist89@yahoo.com Mobile: 09988907446

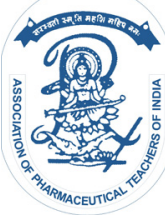

www.ijper.org 
acceptance as new drug delivery systems, because they are easy to administer and lead to better patient compliance. ${ }^{3}$ In some cases such as motion sickness, sudden episodes of allergic attacks or coughing and unavailability of water, swallowing conventional tablets may be difficult. Particularly the difficulty is experienced by pediatric and geriatric patients. To overcome such problems, Fast disintegrating tablets or orally disintegrating tablets have emerged as an alternative dosage form. ${ }^{4}$ US Food and Drug Administration Center for Drug Evaluation and Research (CDER) defines, in the 'Orange Book', an Fast Disintegrating Tablet as "a solid dosage form containing medicinal substances, which disintegrates rapidly, usually within a matter, when placed upon the tongue. European Pharmacopoeia described ODTs as 'uncoated tablets intended to be placed in the mouth where they disperse rapidly before being swallowed' and as tablets which should disintegrate within $3 \mathrm{~min}-$ utes. ${ }^{5}$ Fast Disintegrating Tablets (FDT) are also known as 'fast dissolving', 'mouth dissolving', 'rapid-dissolve', 'quick disintegrating,, 'orally disintegrating', 'rapimelt', 'fast melts', 'oro-dispersible', 'melt-in-mouth', 'quick dissolving', 'porous tablets. ${ }^{6}$

Recent advances in Novel Drug Delivery Systems (NDDS) aims for enhancing the safety of a drug molecule while maintaining its therapeutic efficacy so as to achieve better patient compliance. ${ }^{7}$ The target populations for these new fast-dissolving/disintegrating dosage forms have generally been pediatric, geriatric, and bedridden or mentally disabled patients. Patients with diarrhea, persistent nausea, vomiting, who are traveling, or who have little or no access to water are also good candidates for FDTs. ${ }^{8}$

Ambroxol Hydrochloride is a potent mucolytic \& mucokinetic, capable of inducing bronchial secretion. It depolymerises mucopolysaccharides directly as well as by liberating lysosomal enzymes network of fibres in tenacious sputum is broken. It is used as expectorant and variety of respiratory disorders including asthma, bronchitis and used in the treatment of cough. It is particularly useful if mucus plugs are present. In pediatrics, the most common triggers are viral illnesses such as those that cause the common cold. Due to sore throat conditions, the pediatrics patient experiences difficulty in swallowing a tablet type of dosage form. Liquid dosage forms are having their own limitation from stability and dose measurement perspectives. ${ }^{9}$ Thus, fast disintegrating tablets would serve as an ideal dosage form for pediatric patients. Hence an attempt was made for preparation of fast disintegrating tablet of Ambroxol Hydrochloride with an aim of improving/enhancing patient convenience and compliance, reducing the lag time and providing faster onset of action to relieve the respiratory disorders immediately.

\section{MATERIALS AND METHODS}

\section{Materials}

Ambroxol Hydrochloride was received as gift sample from Trojan Pharma, Baddi, India. Microcrystalline cellulose (Avicel PH-102) was obtained as gift sample from NB Entrepreneurs, Nagpur, India. Sodium Starch Glycolate (Primogel, Explotab) and directly compressible Mannitol (D-Mannitol) were purchased from Qualikems Fine Chem Pvt. Ltd. Sodium Strearyl Fumarate was Purchased from Himedia. Sodium Saccharin was purchased from Loba Chemie, Mumbai and talc from Nice Chemicals Private Limited, Hyderabad, India. All other chemicals and reagents were used of either pharmacopoeial or analytical grade.

\section{Methods}

\section{Selection of Excipients and Optimization of their Con- centration}

The most important parameter that needs to be optimized in the development of fast disintegrating tablets is the disintegration time. Fast disintegrating tablets were prepared firstly using different excipients (binders and superdisintegrants) and then evaluated for various parameters like friability, hardness and disintegration time to select the best combination for formulation of fast disintegrating tablets. The combination with lowest disintegration time, optimum hardness and friability was selected for further study.

\section{Optimization of Superdisintegrant Sodium Starch Gly- colate (Primogel, Explotab)}

For tablets and capsules which require rapid disintegration, the inclusion of the right superdisintegrant and in its optimum concentration is a prerequisite for optimal bioavailability. Superdisintegrants decrease disintegration time which in turn enhances drug dissolution rate. Thus, the proper choice of superdisintegrant and its consistency of performance are of critical importance to the formulation of rapidly disintegrating dosage forms.

Formulation F1-F6 was prepared to study the effect of type and concentration of superdisintegrants given in (Table 1). Tablets were prepared by direct compression technique. Weighed quantity of Ambroxol Hydrochloride with different concentration of superdisintegrant along with excipients were mixed in geometric progression in a dry and clean mortar. Then the blend was 
Table 1: Formula for 1 tablet (200 $\mathrm{mg})$ of Different Concentration of SSG

\begin{tabular}{|c|c|c|c|c|c|c|}
\hline Ingredients & F1* & F2* & F3* & F4* & F5* & F6* \\
\hline $\begin{array}{l}\text { Ambroxol } \\
\text { Hydrochloride }\end{array}$ & 7.5 & 7.5 & 7.5 & 7.5 & 7.5 & 7.5 \\
\hline SSG & $2(1 \%)$ & $4(2 \%)$ & $8(4 \%)$ & $12(6 \%)$ & $16(8 \%)$ & $20(10 \%)$ \\
\hline PVP K-30 & 4 & 4 & 4 & 4 & 4 & 4 \\
\hline $\begin{array}{l}\text { Sodium Stearyl } \\
\text { Fumarate }\end{array}$ & 3 & 3 & 3 & 3 & 3 & 3 \\
\hline Talc & 3 & 3 & 3 & 3 & 3 & 3 \\
\hline $\begin{array}{l}\text { Sodium } \\
\text { Saccharin }\end{array}$ & 5 & 5 & 5 & 5 & 5 & 5 \\
\hline Mannitol & 175.5 & 173.5 & 169.5 & 165.5 & 161.5 & 157.5 \\
\hline
\end{tabular}

passed through sieve no. 60 for direct compression. The powder blend was then compressed into tablets using $8 \mathrm{~mm}$ punch in multi punch tablet compression machine (Dhiman Industries, India).

Optimization of Polyvinylpyrrolidone (PVP K-30) or Microcrystalline Cellulose (Avicel PH-102) as binder along with Optimized Concentration of Superdisintegrant

Tablets were prepared by direct compression technique. The composition of fast disintegrating tablet was given in (Table 2). Weighed quantity of Ambroxol Hydrochloride with optimized concentration of Sodium Starch Glycolate along with different concentration of binders such as Polyvinylpyrrolidone (PVP K-30) or Microcrystalline Cellulose along with excipients was mixed in geo- metric progression in a dry and clean mortar. Then the blend was passed through sieve no. 60 for direct compression. The powder blend was then compressed into tablets using $8 \mathrm{~mm}$ punch in multi punch tablet compression machine (Dhiman Industries, India).

Final Formulation of Ambroxol Hydrochloride Fast Disintegrating Tablets by Direct Compression Method

Fast disintegrating tablets of Ambroxol Hydrochloride prepared by direct compression method according to the formula given in (Table 3). Weighed quantity of Ambroxol Hydrochloride along with optimized concentration of superdisintegrant and binder along with excipients were mixed in geometric progression in a dry and clean mortar. Then the blend was passed through sieve no.60 for direct compression. The powder blend

\section{Table 2: Formula for 1 tablet (200mg) For the Optimization of PVP K-30 or MCC with optimized concentration of} SSG

\begin{tabular}{|c|c|c|c|c|c|c|c|c|}
\hline $\begin{array}{c}\text { Contents } \\
\text { Formula } \\
\text { No. }\end{array}$ & $\begin{array}{l}\text { Ambroxol } \\
\mathrm{HCl}(\mathrm{mg})\end{array}$ & SSG (mg) & $\begin{array}{l}\text { PVP K- } 30 \\
\quad(\mathrm{mg})\end{array}$ & $\begin{array}{l}\text { MCC } \\
\text { (mg) }\end{array}$ & $\begin{array}{l}\text { Sodium } \\
\text { Stearyl } \\
\text { Fumarate } \\
\text { (mg) }\end{array}$ & $\begin{array}{l}\text { Talc } \\
(\mathrm{mg})\end{array}$ & $\begin{array}{l}\text { Sodium } \\
\text { Saccharin } \\
(\mathrm{mg})\end{array}$ & $\begin{array}{c}\text { Mannitol } \\
(\mathrm{mg})\end{array}$ \\
\hline F1 & 7.5 & 8 & 2 & - & 2 & 2 & 5 & 173.5 \\
\hline $\mathrm{F} 2$ & 7.5 & 8 & 4 & - & 2 & 2 & 5 & 171.5 \\
\hline F3 & 7.5 & 8 & 6 & - & 2 & 2 & 5 & 169.5 \\
\hline F4 & 7.5 & 8 & 8 & - & 2 & 2 & 5 & 167.5 \\
\hline F5 & 7.5 & 8 & 10 & - & 2 & 2 & 5 & 165.5 \\
\hline F6 & 7.5 & 8 & 12 & - & 2 & 2 & 5 & 163.5 \\
\hline F7 & 7.5 & 8 & 14 & & 2 & 2 & 5 & 161.5 \\
\hline F8 & 7.5 & 8 & - & 2 & 2 & 2 & 5 & 173.5 \\
\hline F9 & 7.5 & 8 & - & 4 & 2 & 2 & 5 & 171.5 \\
\hline F10 & 7.5 & 8 & - & 6 & 2 & 2 & 5 & 169.5 \\
\hline F11 & 7.5 & 8 & - & 8 & 2 & 2 & 5 & 167.5 \\
\hline F12 & 7.5 & 8 & - & 10 & 2 & 2 & 5 & 165.5 \\
\hline F13 & 7.5 & 8 & - & 12 & 2 & 2 & 5 & 163.5 \\
\hline F14 & 7.5 & 8 & - & 14 & 2 & 2 & 5 & 161.5 \\
\hline
\end{tabular}


Table 3: Formula of Ambroxol Hydrochloride FDT Prepared by Direct Compression Method (Data in mg)

\begin{tabular}{|l|c|c|}
\hline Ingredients & Formula for 1 Tablet $\mathbf{2 0 0} \mathbf{~ m g})$ & Formula for $\mathbf{1 1 0}$ Tablets $\mathbf{( 2 0 0 ~} \mathbf{~ m g})$ \\
\hline Ambroxol HCl $\mathbf{m g})$ & 7.5 & 825 \\
\hline SSG & 8 & 220 \\
\hline MCC & 2 & 550 \\
\hline Sodium Stearyl Fumarate & 5 & 330 \\
\hline Talc & 3 & 550 \\
\hline Sodium Saccharin & 5 & 18645 \\
\hline Mannitol & 169.5 & \\
\hline mg- milligram; MCC: Microcrystalline Cellulose; SSG: Sodium Starch Glycolate. & \\
\hline
\end{tabular}

was then compressed into tablets using $8 \mathrm{~mm}$ punch in multi punch tablet compression machine.

\section{Evaluation Parameters}

\section{Weight Variation}

Twenty tablets were selected, weighed on Digital Weighting Balance (Ohaus, USA) and average weight was determined. Then individual tablets were weighed and the individual weight was compared with an average weight. $^{10}$

\section{Thickness}

Thickness of tablets was determined using Vernier Caliper (Indian caliper industries, Ambala, India). Three tablets from each batch were used and an average value was calculated. ${ }^{10}$

\section{Hardness}

The crushing strength of the tablets was measured using a Monsanto Hardness Tester (Perfit). Three tablets from each formulation batch were tested randomly and the average reading noted. The hardness is measured in $\mathrm{kg} / \mathrm{cm}^{2}{ }^{11}$

\section{Friability}

Ten tablets were weighed and placed in a Roche Friabilator (Veego, India) and the equipment was rotated at 25 rpm for $4 \mathrm{~min}$. The tablets were taken out, de-dusted and reweighed. The percentage friability of the tablets was measured as per the following formula. ${ }^{12}$

$$
\% \text { of friability }=\frac{\text { Initial weight }- \text { Final weight }}{\text { Initial weight }} \times 100
$$

\section{In-vitro Disintegration Test}

The test was carried out on 6 tablets using Digital Tablet Disintegration Tester (Veego, India). Distilled water at $37^{\circ} \mathrm{C} \pm 2^{\circ} \mathrm{C}$ was used as a disintegration media and the time in second taken for complete disintegration of the tablet with no palable mass remaining in the apparatus was measured in seconds. ${ }^{13}$

\section{Wetting Time}

A petridish containing $6 \mathrm{ml}$ of distilled water was taken. A tablet containing a small quantity of amaranth color was placed on this. Time required for the upper surface of the tablet to become complete red was noted. ${ }^{14}$

\section{Drug Content Uniformity}

Ten tablets $(200 \mathrm{mg})$ were powdered in mortar pestle and the blend equivalent to $7.5 \mathrm{mg}$ Ambroxol Hydrochloride was weighed and dissolved in $100 \mathrm{ml}$ of $6.8 \mathrm{pH}$ phosphate buffer solutions. The solution was sonicated, filtered through whatman filter paper, suitably diluted with $6.8 \mathrm{pH}$ phosphate buffer and the drug content was analyzed by using Double Beam UV Spectrophotometer (UV-1800 Shimadzu) at $244 \mathrm{~nm}$ respectively. Each sample was analyzed in triplicate. ${ }^{15}$

\section{In-vitro Dissolution Study}

The release of from formulated FDTs was determined using USP eight stage dissolution testing apparatus- 2 (paddle method) (Lab, India). The dissolution test was performed using $500 \mathrm{ml}$ of Phosphate buffer solution, $\mathrm{pH} 6.8$ at $37 \pm 0.5^{\circ} \mathrm{C}$ and $50 \mathrm{rpm}$. A sample $(5 \mathrm{ml})$ of the solution was withdrawn from the dissolution apparatus at specific time intervals and the samples were replaced with fresh dissolution medium. The samples were filtered through whatman filter paper. Absorbance of these solutions was measured at $244 \mathrm{~nm}$ using a Double Beam UV Spectrophotometer (UV-1800 Shimadzu). Cumulative percentage (\%) drug release was calculated using standard plot of Ambroxol Hydrochloride. ${ }^{15}$

\section{Drug-Excipient Compatibility Studies}

These studies were performed in order to confirm the drug-excipient interaction. These studies mainly include FTIR Spectroscopy. FTIR spectra of pure drug and formulated FDT containing drug was recorded on FTIR Spectrophotometer (Bruker, USA). The scanning range was 4000 to $600 \mathrm{~cm}^{-1}$ and the resolution was $1 \mathrm{~cm}^{-1}$. The 
scans were evaluated for presence of principal peaks of drug, shifting and masking of drug peaks and appearance of new peaks due to excipient interaction. This spectral analysis was employed to check the compatibility of drugs with the excipients used. ${ }^{16}$

\section{Accelerated Stability Studies}

Accelerated stability studies are conducted at temperature of $40 \pm 2{ }^{\circ} \mathrm{C}$ (oven) and at ambient humidity as well as at room temperature. The tablets were withdrawn on $15^{\text {th }}, 30^{\text {th }}$ day and analyzed for Hardness, Friability, drug content uniformity and in-vitro disintegration time which are the most important parameters for fast disintegrating tablets. ${ }^{17}$

\section{RESULTS AND DISCUSSION}

The present investigation was undertaken to formulate and evaluate fast disintegrating tablets of Ambroxol Hydrochloride by direct compression method using Sodium starch glycolate as a superdisintegrant, mannitol as directly compressible diluent and sodium saccharin was used to enhance palatability. Avicel PH 102 was included in the formulation as a disintegrant and a binder. This grade of microcrystalline cellulose is granular in nature and thus displays excellent flow properties. To impart pleasant taste and improve mouth feel, sodium saccharin was included as sweetening agent which is 400 times sweeter than sucrose. Sodium Stearyl Fumarate was employed as a lubricant instead of Magnesium Stearate not only because of the metallic taste of the latter, but also due to its water solubility and directly compressible features.

Optimization of Superdisintegrant Sodium Starch Glycolate (Primogel, Explotab)

Superdisintegrants are generally used by formulation scientists for developing FDTs or for improvement of solubility for drugs. The primary requirement for such dosage forms is quicker disintegration. The amount of Superdisintegrants was optimized in the formulation of FDTs. The total 6 formulation (F1-F6) were pre- pared using different concentration of Sodium starch glycolate to study its effect on disintegration time. The results for optimization of superdisintegrant concentration in FDTs by direct compression method were given in (Table 4).

From the evaluation parameters, it was observed that $4 \%$ Sodium starch glycolate was the optimum concentration for rapid tablet disintegration on the basis of least disintegration time observed with F3 formulation. The superdisintegrant action of SSG is resulted in hydrophilicity and swelling which in turn causes rapid disintegration. It absorbs water rapidly and swells in water to the extent of $200-300 \%$, disintegrates rapidly. Sodium starch glycolate is used as superdisintegrant in tablet formulation at a concentration of 4-6\%. Above $8 \%$ disintegration times may actually increase due to gelling and its subsequent viscosity producing effects.

Optimization of Polyvinylpyrrolidone (PVP K-30) or Microcrystalline Cellulose (Avicel PH-102) as binder along with Optimized Concentration of Superdisintegrant

The binders such as Polyvinylpyrrolidone (PVP K-30) or Microcrystalline Cellulose was optimized with superdisintegrant concentration to further study the effect of binders on the disintegration time as well as on hardness and friability of tablets of the formulation. Total 14 formulations (F1- F14) were prepared using different concentration of Polyvinylpyrrolidone (PVP K-30) or Microcrystalline Cellulose to study its effect on disintegration time of formulations. The results for optimization of different binder in FDTs by direct compression method were shown in (Table 5).

From the evaluation parameters, it was observed that disintegration time of the formulation was further decreased and tablet hardness and friability within the IP limits. The least disintegration time was observed in F8 formulation i.e. 1\% MCC as compared to F2 formulation i.e. $2 \%$ PVP K-30. Water soluble materials such as PVP K-30 tend to dissolve rather than disintegrate, while insoluble materials like MCC generally produce rapidly disintegrating tablets. Due to the presence of porous morphology, liquid is drawn up or "wicked" into

\begin{tabular}{|l|c|c|c|c|c|c|}
\hline \multicolumn{7}{|c|}{ Table 4: Evaluation Parameters for the Optimization of SSG } \\
\hline $\begin{array}{l}\text { Evaluation } \\
\text { Parameters }\end{array}$ & F1 (1\%) & F2 (2\%) & F3 (4\%) & F4 (6\%) & F5 (8\%) & F6 (10\%) \\
\hline $\begin{array}{l}\text { Weight } \\
\text { variation (IP) }\end{array}$ & Passed & Passed & Passed & Passed & Passed & Passed \\
\hline Friability (\%) & 0.8 & 0.8 & 0.1 & 0.3 & 0.1 & 0.1 \\
\hline $\begin{array}{l}\text { *Hardness (Kg/ } \\
\left.\mathbf{c m}^{2}\right) \pm \text { S.D }\end{array}$ & $2.2 \pm 0.57$ & $1.6 \pm 0.28$ & $1.5 \pm 0.28$ & $1.5 \pm 0.32$ & $2.0 \pm 0.57$ & $1.8 \pm 0.28$ \\
\hline $\begin{array}{l}\text { **Disintegration } \\
\text { time (s) } \pm \text { S.D }\end{array}$ & $80 \pm 3.45$ & $59 \pm 6.67$ & $36 \pm 2.63$ & $48 \pm 6.38$ & $78 \pm 7.39$ & $95 \pm 6.97$ \\
\hline *Average of Three Determinations; **Average of Six Determinations; S.D -Standard Deviation. & & & \\
\hline
\end{tabular}




\begin{tabular}{|c|c|c|c|c|}
\hline $\begin{array}{c}\text { Evaluation Parameters } \\
\text { Formula No. }\end{array}$ & Weight variation (IP) & Friability (\%) & $\begin{array}{c}{ }^{*} \text { Hardness }\left(\mathrm{Kg} / \mathrm{cm}^{2}\right) \\
\pm \mathrm{S} . \mathrm{D}\end{array}$ & $\begin{array}{l}\text { ** Disintegration time } \\
\text { (s) } \pm \text { S.D }\end{array}$ \\
\hline F1 & Passed & 0.1 & $2.2 \pm 0.28$ & $120 \pm 1.78$ \\
\hline F2 & Passed & 0.2 & $1.8 \pm 0.28$ & $80 \pm 1.67$ \\
\hline F3 & Passed & 0.5 & $2.0 \pm 0.00$ & $96 \pm 2.89$ \\
\hline F4 & Passed & 0.3 & $3.2 \pm 0.76$ & $114 \pm 2.40$ \\
\hline F5 & Passed & 0.3 & $1.6 \pm 0.50$ & $112 \pm 5.16$ \\
\hline F6 & Passed & 0.8 & $2.5 \pm 0.50$ & $120 \pm 5.77$ \\
\hline F7 & Passed & 0.8 & $2.0 \pm 0.00$ & $168 \pm 5.43$ \\
\hline F8 & Passed & 0.1 & $1.5 \pm 0.50$ & $66 \pm 2.13$ \\
\hline F9 & Passed & 0.1 & $1.5 \pm 0.28$ & $90 \pm 1.34$ \\
\hline F10 & Passed & 0.2 & $1.5 \pm 0.28$ & $126 \pm 1.10$ \\
\hline F11 & Passed & 0.1 & $1.8 \pm 0.28$ & $167 \pm 1.32$ \\
\hline F12 & Passed & 0.1 & $1.5 \pm 0.28$ & $182 \pm 2.08$ \\
\hline F13 & Passed & 0.1 & $1.8 \pm 0.28$ & $196 \pm 2.92$ \\
\hline F14 & Passed & 0.1 & $1.8 \pm 0.28$ & $205 \pm 1.96$ \\
\hline
\end{tabular}

\begin{tabular}{|c|c|}
\hline \multicolumn{2}{|c|}{ Table 6: Evaluation Parameters for Ambroxol Hydrochloride FDT } \\
\hline Evaluation Parameters & Results \\
\hline Weight variation (IP) & Passed \\
\hline${ }^{*}$ Thickness $(\mathrm{mm}) \pm$ S.D & $3.67 \pm 0.06$ \\
\hline *Hardness $\left(\mathrm{Kg} / \mathrm{cm}^{2}\right) \pm$ S.D & $1.5 \pm 0.00$ \\
\hline Friability (\%) & 0.6 \\
\hline${ }^{* *}$ Disintegration Time (s) \pm S.D & $62 \pm 7.79$ \\
\hline *Wetting Time (s) \pm S.D & $37 \pm 2.51$ \\
\hline${ }^{*}$ Drug Content Uniformity (mg) \pm S.D & $103.6 \pm 6.26$ \\
\hline *Average of Three Determinations; ** Average of Six Determinations; S.D -Standard Deviation. \\
\hline
\end{tabular}

these pathways through capillary action and rupture the interparticulate bonds causing the tablet to break apart. Therefore 1\% Microcrystalline Cellulose was selected as optimum binder concentration selected for final formulation of Ambroxol Hydrochloride FDT.

\section{Evaluation Parameters for Ambroxol Hydrochloride Fast Disintegrating Tablet}

Final formulation of Ambroxol Hydrochloride Fast Disintegrating Tablets were tested for all the official test of tablet and were found to be within limits as given in (Table 6). Percent weight variation was well within the acceptable limit for uncoated tablets as per Indian Pharmacopoeia. It is well known to formulation scientists that the tablets with more hardness show longer disintegration time. Since mechanical integrity is of paramount importance in successful formulation of FDTs, hence the hardness of tablets was determined. The friability of Ambroxol Hydrochloride FDT was less than 1\% indicated the formulated tablets have good mechani- cal strength. The content uniformity of the prepared Ambroxol Hydrochloride FDT was complied with IP Specifications. No tablet from ten tablets lies out of the range of $85-115 \%$ of the label claim. These results indicated that the dosage form had uniform distribution and proper dose of the active ingredient. The wetting time and disintegration time was practically good for formulation. According to EP, the Fast Disintegrating Tablets must disintegrate within 3 minutes, but the formulated FDTs shown low DT indicating suitability of formulation for orally disintegrating tablet.

\section{In-vitro Dissolution Study}

In vitro dissolution studies showed that more than $85 \%$ of the drug was released from the formulation within 17 minutes. The rapid drug dissolution might be due to easy breakdown of particle by superdisintegrant action. From in-vitro dissolution data it was observed that $92.23 \pm 0.15 \%$ of Ambroxol Hydrochloride released in 
20 minutes indicates that the tablet complies as per IP specifications i.e. $85 \%-110 \%$ as shown in (Figure. 1).

\section{Drug-Excipient Compatibility Studies}

The results obtained with IR studies showed that there was no interaction between the drug and other excipients used in the formulation. The FTIR of Ambroxol Hydrochloride shown intense band at $627.38 \mathrm{~cm}^{-1}$, $1629.54 \mathrm{~cm}^{-1}$ and $1288.07 \mathrm{~cm}^{-1}$ corresponding to the presence of functional groups such as Aliphatic Bromo compound, Secondary Amine and Secondary Alcohol. The FTIR of Ambroxol Hydrochloride FDT formulation shown intense bands at $692.40 \mathrm{~cm}^{-1}, 1620.24 \mathrm{~cm}^{-1}$ and $1281.04 \mathrm{~cm}^{-1}$ indicates no change in the functional groups, confirmed undisturbed structure of Ambroxol Hydrochloride which indicates no drug-excipient interaction as shown in (Figure 2 and Figure 3).

\section{Accelerated Stability Studies}

In the present study, stability studies were carried out on formulated Ambroxol Hydrochloride FD'Ts (Formulated in three primary batches) wrapped in aluminium foil to prevent the formulation from exposure to light to simulate the aluminum packaging i.e. Alu Alu packing of drug products and stored in air-tight containers which is impermeable to solid, liquid and gases, under the following condition for one month period as prescribed by ICH guidelines for accelerated study. During the stabil-

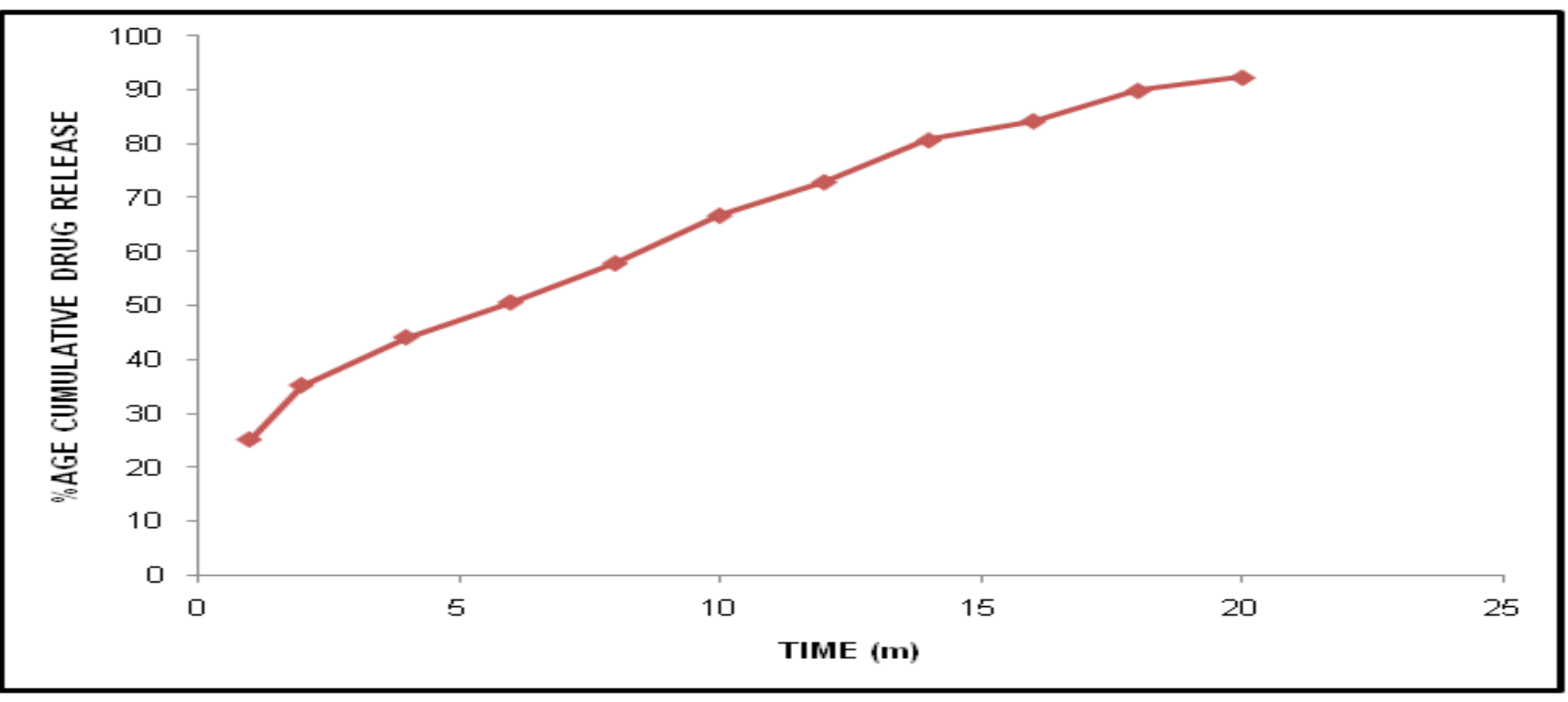

Figure 1: In vitro Dissolution Profile of Ambroxol Hydrochloride FDT

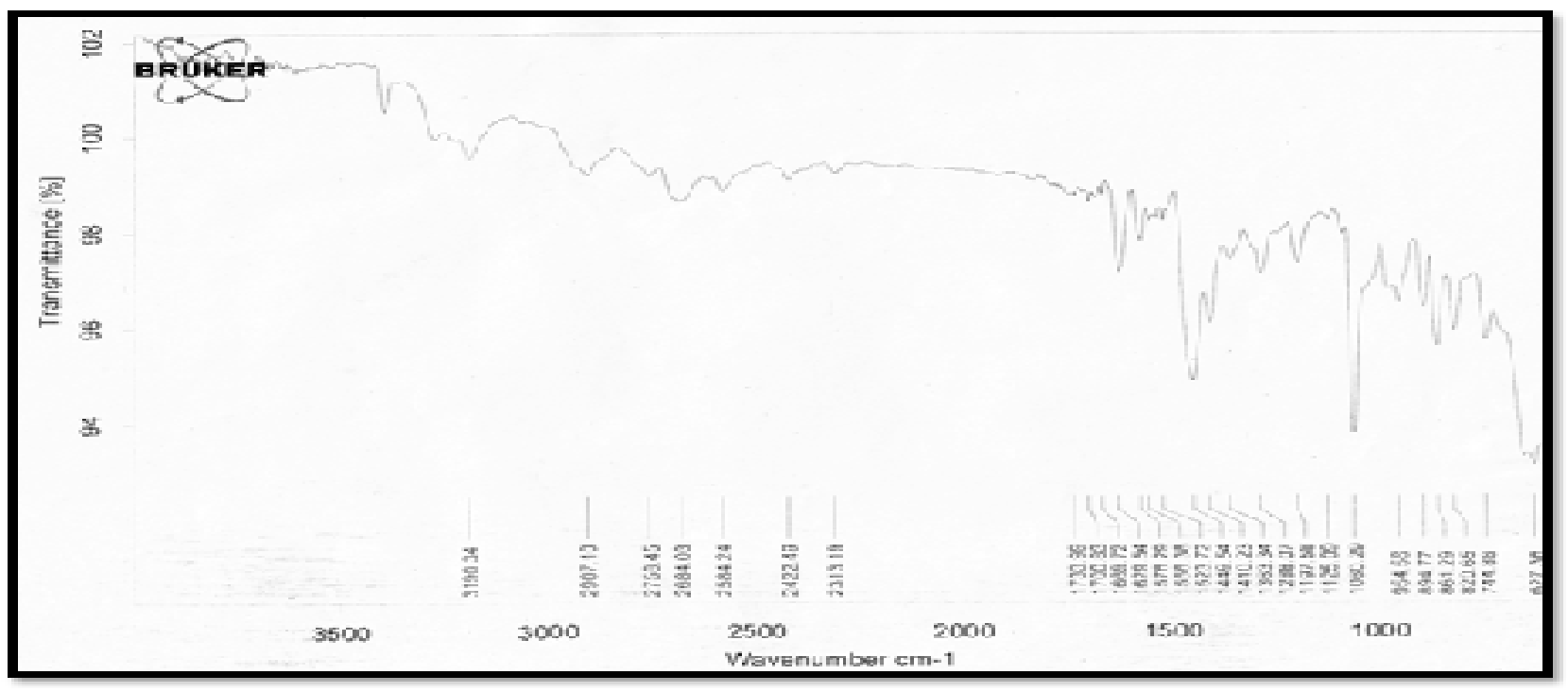

Figure 2: FTIR Spectra of Ambroxol Hydrochloride 


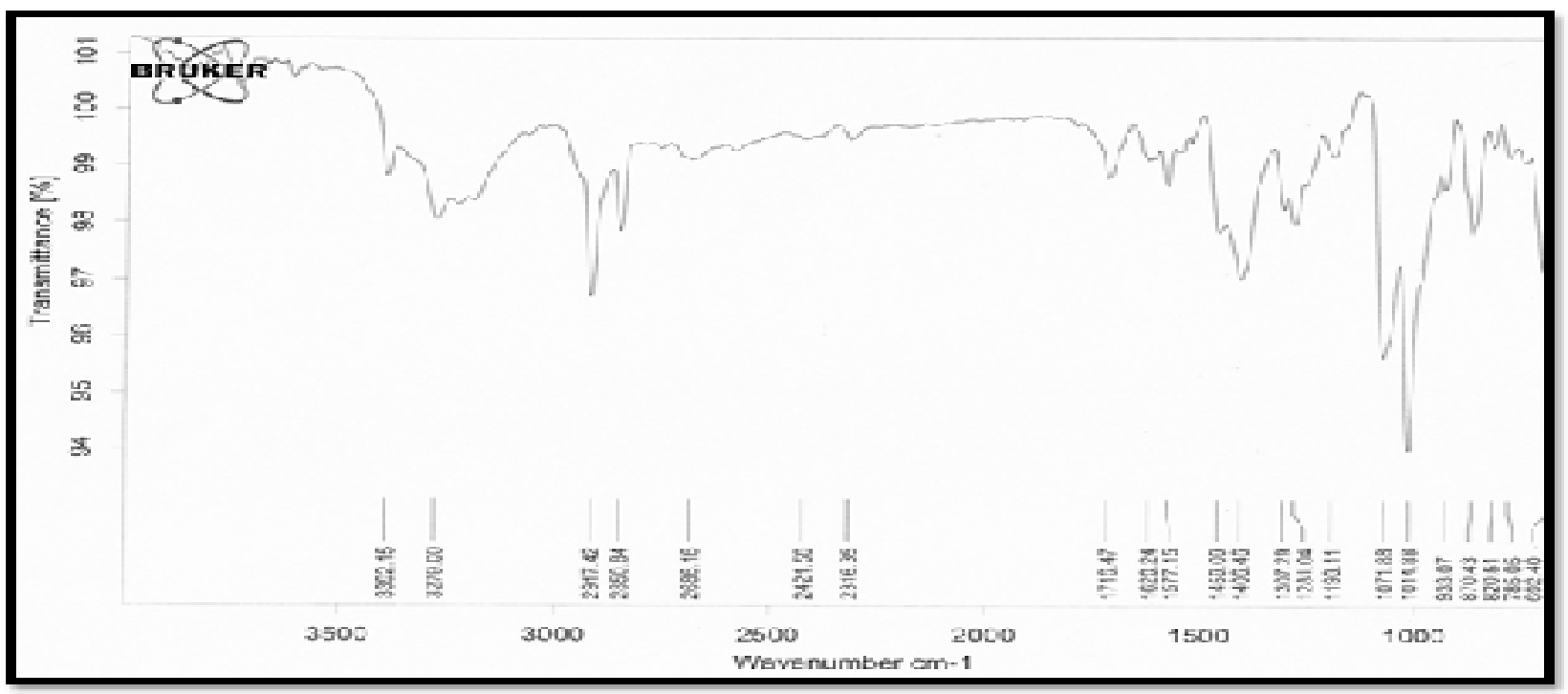

Figure 3: FTIR Spectra of Ambroxol Hydrochloride FDT Formulation

\begin{tabular}{|c|c|c|c|c|c|c|c|c|c|}
\hline \multicolumn{10}{|c|}{ Three Primary Batches } \\
\hline \multirow{2}{*}{$\begin{array}{l}\text { Time Interval } \\
\text { Evaluation } \\
\text { Parameters }\end{array}$} & \multicolumn{3}{|c|}{0 Day } & \multicolumn{3}{|c|}{ 15th Day } & \multicolumn{3}{|c|}{ 30th Day } \\
\hline & B-1 & B-2 & B-3 & B-1 & B-2 & B-3 & B-1 & B-2 & B-3 \\
\hline $\begin{array}{l}{ }^{*} \text { Hardness }(\mathrm{Kg} / \\
\left.\mathrm{cm}^{2}\right) \pm \text { S.D }\end{array}$ & $1.3 \pm 0.29$ & $1.7 \pm 0.50$ & $1.5 \pm 0.00$ & $1.8 \pm 0.29$ & $2.0 \pm 0.29$ & $1.5 \pm 0.00$ & $2.2 \pm 0.5$ & $1.7 \pm 0.29$ & $1.7 \pm 0.29$ \\
\hline Friability (\%) & 0.6 & 0.4 & 0.6 & 0.3 & 0.3 & 0.2 & 0.4 & 0.3 & 0.5 \\
\hline $\begin{array}{l}\text { *Drug Content } \\
\text { Uniformity (mg) } \\
\text { 土 S.D }\end{array}$ & $98.8 \pm 3.36$ & $97.6 \pm 2.34$ & $96.8 \pm 2.42$ & $96.5 \pm 2.14$ & $94.4 \pm 2.67$ & $96.4 \pm 3.64$ & $95.8 \pm 2.76$ & $93.6 \pm 1.34$ & $95.6 \pm 2.74$ \\
\hline $\begin{array}{l}{ }^{* *} \text { Disintegration } \\
\text { Time (s) } \pm \text { S.D }\end{array}$ & $62 \pm 7.79$ & $67 \pm 8.64$ & $56 \pm 7.30$ & $67 \pm 5.06$ & $70 \pm 7.18$ & $72 \pm 8.09$ & $74 \pm 7.43$ & $66 \pm 10.27$ & $69 \pm 7.23$ \\
\hline
\end{tabular}

Table 8: Stability studies of Ambroxol Hydrochloride FDT at Room Temperature and at Ambient Humidity

\begin{tabular}{|c|c|c|c|c|c|c|c|c|c|}
\hline \multicolumn{10}{|c|}{ Three Primary Batches } \\
\hline \multirow{2}{*}{$\begin{array}{l}\text { Time Interval } \\
\text { Evaluation } \\
\text { Parameters }\end{array}$} & \multicolumn{3}{|c|}{0 Day } & \multicolumn{3}{|c|}{ 15th Day } & \multicolumn{3}{|c|}{ 30th Day } \\
\hline & B-1 & B-2 & B-3 & B-1 & B-2 & B-3 & B-1 & B-2 & B-3 \\
\hline $\begin{array}{l}{ }^{*} \text { Hardness }(\mathrm{Kg} / \\
\mathrm{cm} 2) \pm \text { S.D }\end{array}$ & $1.3 \pm 0.29$ & $1.7 \pm 0.50$ & $1.5 \pm 0.00$ & $1.4 \pm 0.00$ & $1.5 \pm 0.00$ & $1.7 \pm 0.29$ & $1.3 \pm 0.5$ & $1.5 \pm 0.29$ & $1.5 \pm 0.29$ \\
\hline Friability (\%) & 0.6 & 0.4 & 0.6 & 0.3 & 0.2 & 0.2 & 0.4 & 0.2 & 0.3 \\
\hline $\begin{array}{l}\text { *Drug Content } \\
\text { Uniformity } \pm \text { S.D }\end{array}$ & $98.8 \pm 3.36$ & $97.6 \pm 2.34$ & $96.8 \pm 2.42$ & $99.5 \pm 2.14$ & $94.5 \pm 2.67$ & $94.8 \pm 1.23$ & $98.3 \pm 2.74$ & $95.4 \pm 2.36$ & $95.7 \pm 1.71$ \\
\hline $\begin{array}{l}{ }^{* *} \text { Disintegration } \\
\text { Time (s) } \pm \text { S.D }\end{array}$ & $62 \pm 7.79$ & $67 \pm 8.64$ & $56 \pm 7.30$ & $63 \pm 7.60$ & $64 \pm 4.44$ & $65 \pm 6.18$ & $69 \pm 3.64$ & $67 \pm 3.05$ & $58 \pm 7.31$ \\
\hline
\end{tabular}

ity studies the product is exposed to normal condition of temperature and humidity. However the studies will take a longer time and hence it would be convenient to carry out accelerated stability studies, where the product is stored under extreme condition of temperature and humidity. The stability data of formulation was given in (Table 7 and Table 8).

The result of the stability study indicated that there were not much differences observed in hardness, disintegration time, drug content uniformity and friability 
before and after the storage period at room temperature and at ambient humidity but at temperature of $40^{\circ} \mathrm{C} \pm$ $2^{\circ} \mathrm{C}$ and at ambient humidity, hardness was increases with time, prolonged the DT of the tablet, the probable reason was loss of moisture from tablets but in all cases, DT is within the specified EP limit (within 3 min.). This indicates that formulation is fairly stable at both storage conditions.

\section{CONCLUSION}

Fast disintegrating tablet is a promising approach with a view of obtaining faster action of the drug and would be advantageous in comparison to currently available liquid dosage forms. The FDT dosage form had a good balance over disintegration time and mechanical strength. The prime objective of the study was to develop Ambroxol Hydrochloride fast disintegrating tablet by using commonly available excipients and conventional technology. From the above study, it was concluded that by employing commonly available pharmaceutical excipients such as superdisintegrants, hydrophilic and swellable excipients and proper filler a fast disintegrating tablet of Ambroxol Hydrochloride for pediatrics used in respiratory disorders were formulated successfully with desired characteristics which disintegrated rapidly; provide rapid onset of action and enhance the patient convenience and compliance. The technique adopted was found to be economical and industrially feasible.

\section{ACKNOWLEDGEMENT}

An author is highly acknowledged to NB Entrepreneurs, Nagpur and Trojan Pharma, Baddi, India for providing gift samples of Avicel PH-102 and Ambroxol Hydrochloride and also to Dr. Mahendra Singh Rathore for his valuable suggestions, and to CT Institute of Pharmaceutical Sciences, Jalandhar, for their efforts to facilitate the use of the necessary instruments and materials required during the entire course of this research work.

\section{CONFLICTS OF INTEREST}

The author declares that he does not have any financial and personal relationships with other people or any other organizations that could inappropriately influence this research work.

\section{REFERENCES}

1. Pahwa R, Piplani M, Sharma PC, Kaushik D, Nanda S. Orally Disintegrating Tablets - Friendly to Pediatrics and Geriatrics. Archives Applied Sci. 2010; 2(2): 35-48.

2. Divate S, Kavitha K, Sockan GN. Fast Disintegrating Tablets- An Emerging Trend. Int J Pharm Sci Rev Res. 2011; 6(2): 18-22.

3. Panigrahi R, Behera S. A Review on Fast Dissolving Tablets. Webmed Central Quality and Patient. 2010; 1(9): 1-17.

4. Slowson M, Slowson S. What to do when patients cannot swallow their medications. Pharma Times. 1985; 51: 90-6.

5. Nayak AK, Manna K. Current Developments in Orally Disintegrating Tablet Technology. J Pharm Educ Res. 2011; 2(1): 21-34.

6. Sreenivas SA, Dandagi PM, Gadad AP, et al. Orodispersible Tablet: NewFanged Drug Delivery System-A Review. Indian J Pharm Edu Res. 2005; 39(4): 177-81.

7. Corveleyn S, Remon JP. Formulation and Production of Rapidly Disintegrating Tablets by Lyophilisation using Hydrochlorothiazide as a Model Drug. Int J Pharm. 1997; 152(2): 215-25.

8. Prajapati BG, Ratnakar N. A Review on Recent patents on Fast Dissolving Drug System. Int J Pharm Tech Res. 2009; 1(3): 790-8.

9. Tripathi KD. Essential of Medical Pharmacology. 6th ed. New Delhi: Jaypee Brothers Medical Publisher; 2008.

10. Jadhav SB, Kaudewar DR, Kaminwar GS, et al. Formulation and Evaluation of Dispersible Tablets of Diltiazem Hydrochloride. Int J Pharm Tech Res. 2011; 3(3): 1314-21.

11. Metker V, Kumar A, Pathak N, Padhee K, Sahoo S. Formulation and Evaluation of Orodispersible Tablets of Lornoxicam. Int J Drug Dev Res. $2011 ; 3(1): 281-5$.

12. Arya A, Sharma S, Kumar J, Chandra A, Jaiswal P. Formulation and Evaluation of Mouth Dissolving Tablets of Ranitidine $\mathrm{HCl}$. Int J Pharm Tech Res. 2010; 2(2): 1574-7.

13. Parmar RB, Baria AH, Tank HM, Faldu SD. Formulation and Evaluation of Domperidone Fast Dissolving Tablets. Int J Pharm Tech Res. 2009; 1(3): 483-7.

14. Senthilnathan B, Rupenagunta A. Formulation Development and Evaluation of Venlafaxine Hydrochloride Orodispersible Tablets. Int J Pharm Sci. Res. 2011; 2(4): 913-21.

15. Anjankumar PB, Nazmuddin M, Kulkarni U, Hariprasanna RC. Formulation and evaluation of lornoxicam fast dissolving tablet. Int Res J Pharm. 2011; 2(4): 130-3.

16. Mohire NC, Yadav AV. Novel Approach to Formulate ß-Cyclodextrin Complexed Mouth Dissolving Tablet of Metronidazole and its in-vitro Evaluation. J Pharm Res. 2010; 3(3): 662-7.

17. $\mathrm{ICH}$ Harmonised Tripartite Guideline. Cover Note for Revision of $\mathrm{Q} 1 \mathrm{~A}(\mathrm{R})$ Stability Testing of New Drug Substances and Products. Q1A (R2) 9. 